\title{
Identifying Factors That Hinder the Acceptance of Chinese Brands among US Consumers
}

\author{
Kathryn Virzi, Carol Parrington \\ Graduate School of Business and Management, Fremont College, Cerritos, CA, USA \\ Email: kathryn_virzi@yahoo.com
}

How to cite this paper: Virzi, K. and Parrington, C. (2019) Identifying Factors That Hinder the Acceptance of Chinese Brands among US Consumers. Open Access Library Journal, 6: e5513.

https://doi.org/10.4236/oalib.1105513

Received: May 31, 2019

Accepted: July 28, 2019

Published: July 31, 2019

Copyright $\odot 2019$ by author(s) and Open Access Library Inc.

This work is licensed under the Creative Commons Attribution International License (CC BY 4.0).

http://creativecommons.org/licenses/by/4.0/

(c) (i) Open Access

\begin{abstract}
China has become a major player in the global economy over the past decade. Recent political turmoil between China and the US coupled with the rising rates of China's currency has prompted the Chinese government to invest in building brand equity among Chinese brand names ( $\mathrm{Si}, 2014)$. In spite of making large financial investments, setting up corporate headquarters in the US, and receiving continuous government backing, Chinese multinational companies (MNCs) have had little success with building brand equity in the US (Lipin, 2014; Gondhia, 2015). The purpose of this study was to identify factors that are hindering the acceptance of Chinese brand names among US consumers. A mixed-method, non-experimental design was used to identify common perceptions that US consumers have about Chinese brands. A survey containing six quantitative and three qualitative questions was completed by 1287 US consumers who were age 18 or older. Results revealed that a lack of awareness and recognition are the primary factors contributing to this phenomenon. In addition, it was discovered that brand trust was connected to perceived quality, reputation, familiarity, and quality control.
\end{abstract}

\section{Subject Areas}

Consumer Behavior, International Economics

\section{Keywords}

Chinese Brands, Brand Management, Chinese Multinational Corporations, US Consumers, Consumer Based Brand Equity (CBBE)

\section{Introduction}

The global economy has grown larger and more complex since the start of the 20th century in terms of outsourcing and trade, foreign direct investments, 
technological advancements and trade agreements. These developments have all contributed to the growth of multinational corporations among emerging economies [1]. Even if a company does not consider itself part of the global economy, all businesses have been affected in some way by the economic reality of globalization [2]. Two of the largest global players in terms of nominal gross domestic product are the US and China. In 2015, China became the largest economy in the world, surpassing the US in terms of purchasing power parity by $\$ 60$ billion dollars. China has sustained this position for the last four years [3].

The US economy is highly connected to China's economy, predominantly through imports. The US Census Bureau listed China as the capital producer of US goods with imports to the US totaling more than $\$ 400$ billion annually since 2012 until it passed the $\$ 500$ billion mark in 2017 [4]. In fact, a US consumer may find it difficult to find a product that does not have "made in China" stitched into the label. It is clear that both countries are primary players in the global economy and that China has a strong economic partnership with the US. Despite these ties, Chinese brand names are scarcely recognized by US consumers. In fact, two separate studies conducted in 2013, one by marketing company Millward Brown and the other by e-commerce firm HD Trade Services, found that only $6 \%$ of US participants could name even one Chinese brand [5]. This is important because a brand's country of origin has become important in the context of globalization [6].

\section{Need}

The global crash of 2008 and the political turmoil experienced among nations over the past decade has brought to light the need for larger economies to be self-sustaining outside of FDI and trade dealings [7]. This is particularly evident in the recent tariff wars between the US and China that may lead to massive reduction in Chinese imports. Given the massive amount of revenue that imports to the US generate for China, this shift would have a large negative impact on the Chinese economy [8]. To diversify the Chinese economy and promote a better reputation of goods, the Chinese government has set out to improve the image of Chinese brand names on a global level by investing in Chinese multinational corporations (MNCs) who are working toward the same goal [9]. There is a growing need to identify factors that influence the lack of acceptance of products with Chinese brand names among US consumers. In addition, the diversification of successful MNCs has the potential to bring a better balance among economic powers.

The 10-year global economic recession in the early part of the 21st century has not only prompted economists to examine the impact of countries that play a primary role in driving the global economy, but also to consider the damage that can come from global oligopolies [10]. One area of particular concern is the balance of power between those that dominate the world of business and consumers. Although people in developing countries have benefited from access to 
goods and services in an expanding global market, the gap between the rich and poor is widening, and only a few large corporations have infiltrated countries on a truly global scale [2] China's unique position in the global economy has elicited a great deal of speculation as to which direction the country is headed. Although it is still considered a developing country, it houses $20 \%$ of the world's population, it has seen exponential financial growth over the last decade, and it is the largest recipient of foreign direct investments in the world [11]. With recent global downturns in the US and Europe, China's position has been significantly strengthened. However, fluctuations in real exchange rates have benefited western countries but have harmed China's economy. While the US and Europe have seen significant improvements in deficit amounts, China's surplus was reduced by over $\$ 90$ billion, proving to be beneficial for the overall global economy, but not for China [12]. In addition, because China's leading export source is the US, recent tariff hikes and threats by the current administration to further increase import tax have revealed the need to develop additional sources of income [8]. The success of stand-alone Chinese MNCs can spread the distribution of income sources within their country and provide a safety net for their economy.

\section{Corporate Social Responsibility}

Another important factor to consider is the contribution successful Chinese MNCs will add through corporate social responsibility (CSR) projects within the US. One of the most positive outcomes of globalization is the impact that corporations have had on the welfare of the countries where they do business. It has become an expectation among consumers that corporations take part in social responsibility initiatives. Several case studies conducted by Choi, Lim, and Phillipsin 2009 [13] found that CSR practices in Vietnam and China improved Korea's country image. In the US, the automobile industry has been a strong proponent of using CSR as a form of improving company image. These initiatives have been proven to be associated with creating a positive image among both shareholders and consumers. Because China is still considered a developing country, the expectations of social policy initiatives, global economic responsibility, and quality control regulations have little influence on the country's business practices.

Chinese culture has a strong emphasis on reputation and image [14]. As China's position in the global economy is growing in importance, the Chinese government has set out to increase the image of Chinese brand names on a global level by way of heavily subsidizing MNCs who are working toward the same goal [9]. In addition to reputation, research shows that building brand equity has a significant impact on the customer lifetime value of a product or service, which in turn impacts shareholder interest, profit margins, and the acquisition of new consumers [15]. If China can build brand equity in the US through the acceptance of Chinese brand names, not only will the country improve its global im- 
age, the country's interests will expand beyond border interests to include concerns for global economic balances and a healthy world economy. These implications reveal the importance for corporations with Chinese brand names to gain success on a global scale. The problem lies in the reality that this success has been hindered due to the lack of acceptance among American consumers.

\section{Impact of Brand Equity in the US}

All statistics reflect that China is in a good position to develop competitive Chinese MNCs in the US. China's global ranking of technological innovations was 8th among all countries in 2010 and was the only developing country on the Global Innovation Index as reported in Thompson Reuters 2011 and 2016 global reports [16]. In spite of these overwhelming evidences, Chinese brand names have a weak presence in the US. Companies like Lenovo Limited, Haier, and Huawei are all successful Chinese MNCs in the technology and electronics industry on a global scale but remain unknown in the minds of most Americans [5]. Alibaba, one of the largest global e-commerce businesses, had the world's largest initial public offering when it entered the New York Stock Exchange in 2014 [17], yet very few Americans use Alibaba or are even aware that it exists. Verbeke and Kano [18] conducted a study on emerging corporations using a modified version of the new internationalization theory. Research revealed that the failure of emerging Chinese corporations to develop successfully at the post-merger stage was due to failure in their implementation of successful strategies after mergers and acquisitions were successfully completed. This has left China with a plethora of successful joint ventures, but almost no standalone brand names that were born and bred by Chinese corporations.

The US has a large influence on the global opinions of brands. Out of 80 nations measured in one report, the US ranked number one on worldwide brand influence. This ranking was based on a survey done by the BAV Group and the Wharton School of business who surveyed more than 20,000 global citizens to determine which countries are the greatest drivers of trade, travel, investment, and cultural influence. This first-place ranking was largely attributed to its dominating role in the media and entertainment industries [19]. If Americans become more accepting of Chinese brands, the level of brand equity for Chinese brand names will increase dramatically on a global scale.

Statistics show that China has become a prominent player in the advancement of globalization over the past two decades, yet Chinese corporations have struggled to gain brand equity in the US despite large financial support provided by the Chinese government [20]. Several successful Chinese corporations have attempted to break into the US market with little success [21]. The purpose of this study was to identify the factors that hinder the acceptance of Chinese brands among US Consumers. Although there are a variety of studies and measures that look at brand equity, specific studies addressing this phenomenon are scarce and empirical data is lacking in the scholarly realm. A better understanding of the 
knowledge and perceptions that US consumers have about Chinese brand names will fill a gap in the current literature and propel discussion for further research on the topic.

\section{Methodology}

A mixed-method, non-experimental design was used to identify common perceptions that US consumer have about Chinese brands. To ensure the reliability and validity of the survey instrument, questions were developed based on the three most widely used models of consumer-based brand equity (CBBE), namely Aaker's Brand Equity model, Keller's CBBE Pyramid, and Y\&R's BAV Four Pillars. Six quantitative questions were developed using Schivinsky and Dabrowski's CBBE Inventory Scale developed in 2014 [22]. This scale was based on Aaker's Brand Equity model, as were Keller and Y\&R's models. Three qualitative questions were developed to provide short-answer, follow-up data to increase the depth of the analysis. Because the survey was being distributed online, a short survey was needed to ensure a high completion rate. Adding three qualitative questions to the six quantitative questions provided the opportunity to collect in-depth and holistic results with minimal questions. Aaker's Brand Equity model (Figure 1) shows the breakdown of factors that impact CBBE.

\section{Name Awareness}

A total of 1287 completed surveys were received from US residents who were 18 years or older. Participants were asked to choose the answer that best fit into the statement, "I know Chinese brand names". Four options were given $(0,1$, 2, 3 or more). Among the 1287 participants, 1285 responded. A total of 998 (78\%) of participants chose " 0 " for the number of Chinese brand names known,

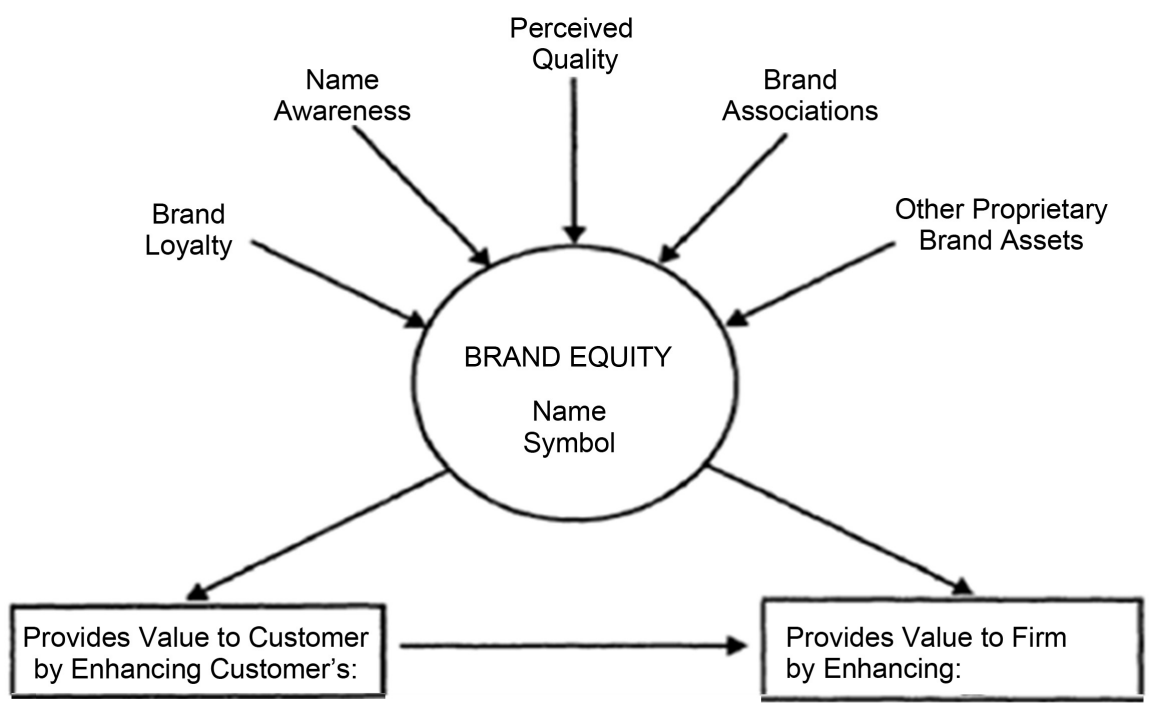

Figure 1. Aaker's brand equity model by D. Aaker, 2009. Managing brand equity: capitalizing on the value of a brand name, p. 32. copyright 2009 by new york: free press. Reprinted with third party permission from Dr. David Aaker. 
140 (11\%) chose "1"; 65 (5\%) chose " 2 "; and $82(6 \%)$ chose "3 or more". The overwhelming skewness of a $78 \%$ response rate of zero reflects that only a slim number of US consumers know one or more Chinese brand names (Figure 2).

The qualitative follow up question asking "List them here" yielded a limited number of responses but was very telling. When asked to list the Chinese brands that they know, 386 of the 1287 participants responded. Among those 386 respondents, 195 participants did not list any correct Chinese brand names. It was discovered that the top Chinese brands recognized by US consumers are ZTE, Lenovo, Alibaba, Huawei, La Choy, and Haier (Figure 3).

The study concluded that US consumers are unfamiliar with Chinese brand names. This is consistent with other research that Chinese corporations have had very little success in building brand equity among US consumers [5] [21].

According to Keller, associations are connected to a consumer's relationship

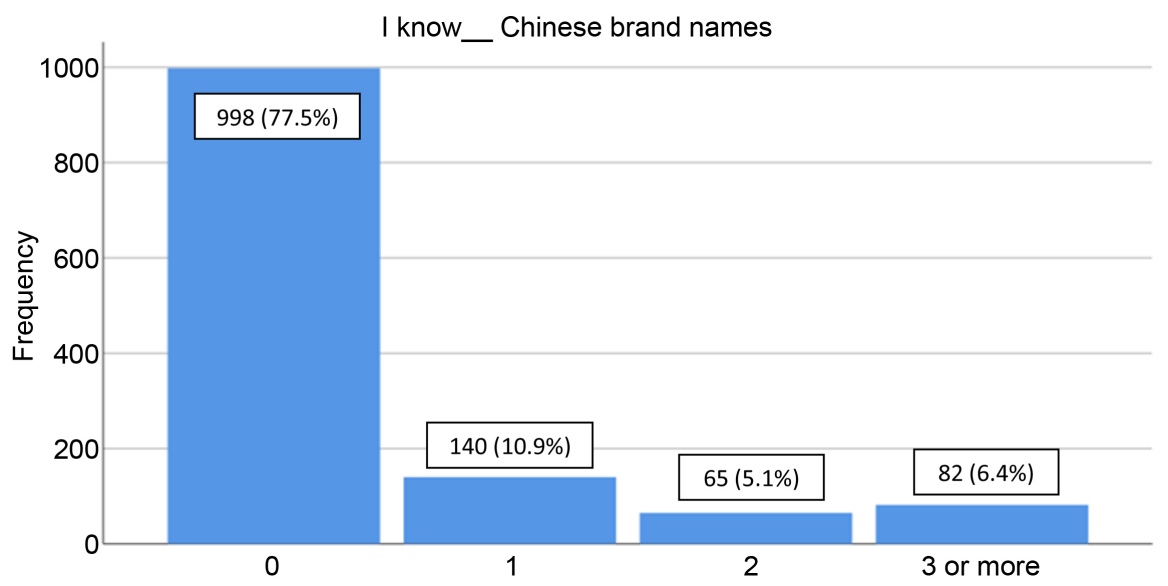

Figure 2. Bar chart displaying frequency results of number of Chinese brands known.

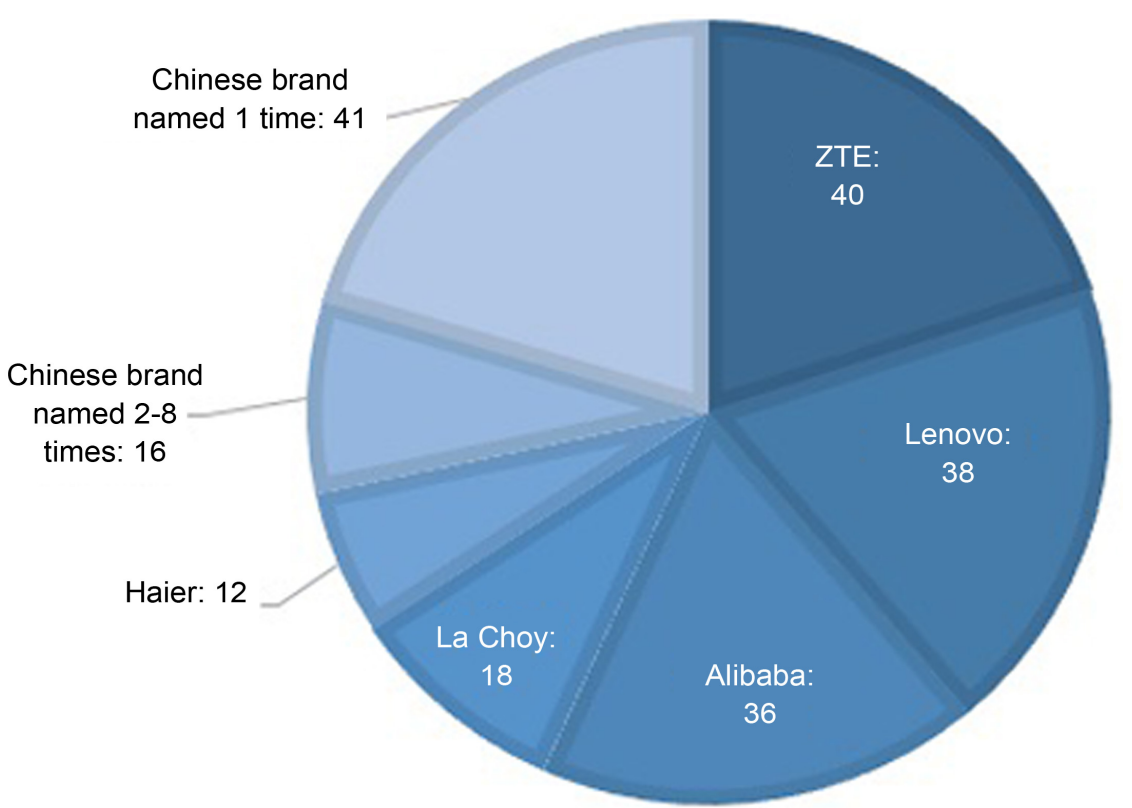

Figure 3. Frequency of Chinese brands listed by number of respondents. 
to the meaning and response of a brand in the areas of perceptions, feelings, and judgements [6]. Aaker includes associations in terms a consumer's reason to buy a specific brand and positive feelings about the brand [23]. Y\&R relates associations to relevance and esteem in terms of a consumer's feelings of appropriateness and regard for a brand [24]. However, as stated previously, a substantial number of US consumers have no significant associations in either a positive or negative sense. This sheds some light on the assertion some researchers have made that the lack of success of Chinese brands stems from negative country-of-origin effects [25] and confirms that the results are more likely connected to a lack of brand awareness, which is also a claim found in literature [5] [21].

\section{Consumer Trust}

A large component of brand equity is consumer trust. Trust falls under the loyalty component of Aaker's model, the relationship aspect of Keller's pyramid, and Y\&R's relevance pillar [15] [26] [27]. In this study, results revealed that US consumers do not have positive associations with Chinese brands in terms of trust. When asked to choose "Agree", "Disagree" or "Not sure" to the statement: I trust the quality of products with Chinese brand names, 1281 people responded. Results revealed that 617 (47.9\%) chose "Not sure" and 496 (38.5\%) chose "Disagree". Only 13.1\% (168) agreed that they trust the quality of Chinese brand names (Figure 4).

Because trust is the assured reliance on the character, ability, strength, or truth of someone or something; one in which confidence is placed, both the answer of "Not sure" and "Disagree" display a lack of trust. Based on the $86.4 \%$ of respondents who did not agree, it was concluded that US residents do not trust the quality of products with Chinese brand names. This reflects that along with awareness and association, trust may have an influence on US consumers' lack of acceptance of Chinese brands.

The primary responses of participants who agreed were related to having a

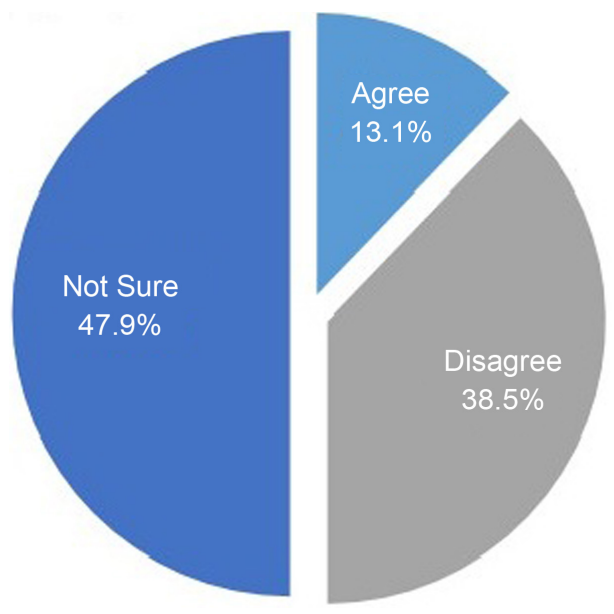

Figure 4. Pie chart displaying percentage of brand trust responses. 
general liking or trust in China and/or Chinese products; having positive personal experiences; and having no reason not to trust. The primary responses of participants who disagreed were related to the poor quality of Chinese products; the poor quality control standards in China which result in toxic materials; corporate responsibility related concerns such as poor labor conditions and environmental damage; bad reputation/reviews; and unfamiliarity of Chinese brands. It should be noted that unfamiliarity, corporate responsibility related concerns, bad reputation, and poor quality were also top responses of those who chose "Not sure" as their response. Other top responses of those who chose "Not Sure" were dependency on product; and inconsistency in experiences of quality. Top responses of "Disagree" and "Not sure" were combined (Figure 5).

Based on the data, it was concluded that quality, unfamiliarity, quality control, bad reputation, and corporate responsibility related issues are the primary reasons US consumers do not trust products with Chinese brand names. This is consistent with recent literature. $\mathrm{Li}, \mathrm{Xu}, \mathrm{Li}$ and $\mathrm{Zhou} \mathrm{[28]} \mathrm{found} \mathrm{that} \mathrm{consistency}$ in reliability (quality) and company integrity (corporate responsibility related) have a large impact on consumer trust regardless of country of origin. Clemons et al. [29] found that unfamiliarity and reputation largely influence a consumer's decision to trust or not trust a brand. Brand recognition is both the level at which the brand is deemed salient and the point of differentiation that makes a brand stand out above others [15] [26]. Brand recognition also plays a large role in the acceptance and trust of a specific brand.

\section{Overall Factors}

To gain a general understanding of what hinders US consumers from buying products with Chinese brand names, the question was asked, "What would make you buy a product with a Chinese name?" Among the 1287 participants, 984 responded to this question. The most prevalent factors listed by consumers included low price (128); reputation (111); good quality (110); good value of price to quality (105); nothing (88); proven assurance (58); knowledge/familiarity (56); and improved CSR (52). The majority of responses are consistent with the trust factors of Chinese brands among US consumers (Figure 6).

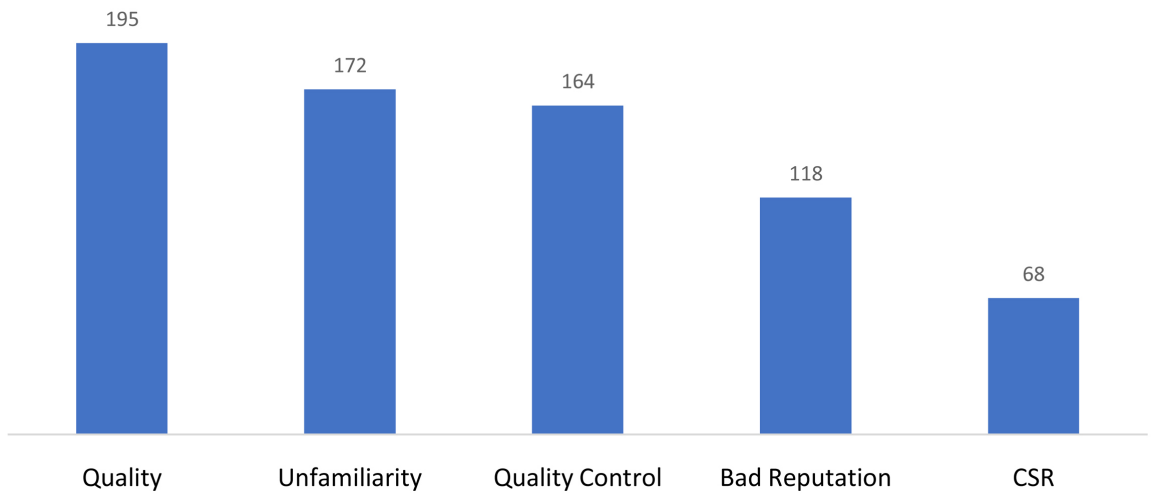

Figure 5. Top responses listed for lack of trust of Chinese brands. 


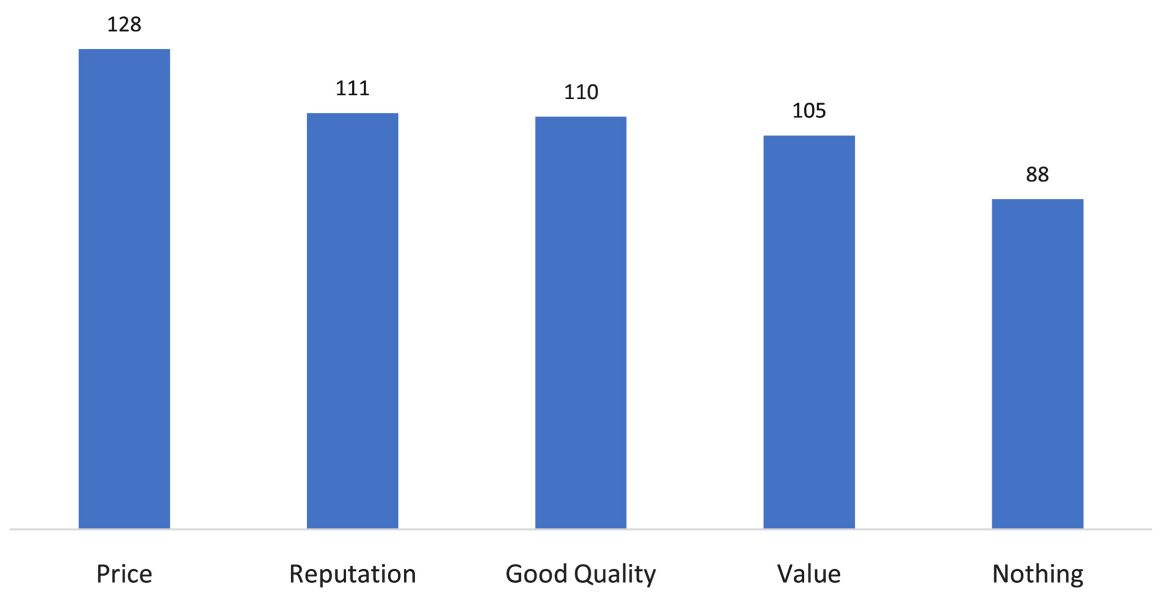

Figure 6. Factors impacting choice to purchase Chinese brands.

Table 1. Frequency of "not sure" responses among quantitative questions.

\begin{tabular}{lcc}
\hline \multicolumn{1}{c}{ Survey Question } & $\begin{array}{c}\text { Frequency } \\
\text { of "Not Sure" }\end{array}$ & $\%$ \\
\hline I like Chinese brands & 825 & $64.1 \%$ \\
I have good memories of products with Chinese brand names & 672 & $52.2 \%$ \\
Chinese brands have a good image & 559 & $43.4 \%$ \\
I would choose a Chinese brand over a generic brand & 608 & $47.2 \%$ \\
I trust the quality of products with Chinese brand names & 617 & $47.9 \%$ \\
\hline
\end{tabular}

Low price; have a good reputation via recommendations from friends, good reviews, and endorsements; good or improved quality; and good value as it relates to price were the most frequent responses, yielding 454 of the 984 replies (46.1\%). Those who said nothing or only if there were no other options totaled $140(14.2 \%)$. This shows that the majority of US consumers would buy products with Chinese brands for reasons beyond a lack of general distrust or hostility for China.

\section{Conclusions}

Several significant conclusions can be drawn from the above data. US consumers are unfamiliar with Chinese brand names. This is a significant finding for two reasons. First, brand awareness is a key component to the three most widely used models that measure consumer-based brand equity [15] [26] [27]. Second, it is difficult to gain a deeper perspective on factors that may hinder the success of Chinese corporations when consumers have little to no recognition of their brands. Gaining brand recognition is the first step in building brand equity. Trust, relevance, differentiation, esteem, perceived quality, and perceived value cannot happen if the brand is not recognized. Brand identity must be determined before the other aspects of positioning can be realized [30].

The lack of familiarity may account for the second significant conclusion. Many US consumers have not made any conclusions about products with Chi- 
nese brand names. Of the five quantitative questions on the survey where participants were given the options to choose "Agree", "Disagree", or "Not Sure", the majority chose "Not Sure" for all responses. A compilation of "Not sure" data is displayed (Table 1).

This is a good indicator that Chinese corporations may have an opportunity to gain brand equity among US consumers because they are not leaning toward either a positive or a negative direction [31].

\section{Recommendations}

Although this study revealed concrete evidence of the factors that contribute to the lack of success of Chinese brand names among US consumers, it only scratches the surface on the topic. Because the study did not examine inferential data, there is an opportunity to narrow the focus to find themes as they relate to gender, age, race, and geographic area. Further study related to this topic could also include a study on the success factors of MNCs in the US who are well known among consumers and a study on success factors of Chinese MNCs in other countries outside the US. Finally, it is recommended that a model combining MNC strategies and brand equity strategies be developed and tested so that an MNC brand equity model can be established.

\section{Conflicts of Interest}

The authors declare no conflicts of interest regarding the publication of this paper.

\section{References}

[1] Midttun, A. (2008) Partnered Governance: Aligning Corporate Responsibility and Public Policy in the Global Economy. Corporate Governance, 8, 406-418. https://doi.org/10.1108/14720700810899158

[2] Sahay, V.S. (2013) Globalization, Urbanization and Migration: Anthropological Dimensions of Trends and Impacts. The Oriental Anthropologist, 13, 305-312. https://search.proquest.com/docview/1512708800?accountid=158816

[3] Oxford Analytica (2015) US/China: US Firms Will Hold Their Own as China Rises. OxResearch Daily Brief Service. https://search.proquest.com/docview/1715676843?accountid=158816

[4] United States Census Bureau (2018) Trade in Goods with China. https://www.census.gov/foreign-trade/balance/c5700.html

[5] Lipin, M. (2014) Chinese Brands Little Recognized in US, but Innovation Helping. VOA.

https://www.voanews.com/east-asia-pacific/chinese-brands-little-recognized-us-inn ovation-helping

[6] Gürhan-Canli, Z., Hayran, C. and Sarial-Abi, G. (2016) Customer-Based Brand Equity in a Technologically Fast-Paced, Connected, and Constrained Environment. AMS Review, 6, 23-32. https://doi.org/10.1007/s13162-016-0079-y

[7] Vizjak, A., Katičić, L. and Vizjak, M. (2016) The Position of the Republic of China in Globalisation Relations. Enterprise Odyssey. International Conference Proceed- 
ings, 504-511. https://search.proquest.com/docview/1815354373?accountid=158816

[8] Li, C., He, C. and Lin, C. (2018) Economic Impacts of the Possible China-US Trade War. Emerging Markets Finance \& Trade, 54, 1557-1577.

https://doi.org/10.1080/1540496X.2018.1446131

[9] Si, Y. (2014) The Development of Outward FDI Regulation and the Internationalization of Chinese Firms. Journal of Contemporary China, 23, 804-821. https://doi.org/10.1080/10670564.2014.882535

[10] Prabhakar, A.C. (2013) Global Economy: New Trends. Journal of Applied Finance and Banking, 3, 229-244.

https://search.proquest.com/docview/1400457195?accountid=158816

[11] Paul, J. (2016) The Rise of China: What, When, Where, and Why? The International Trade Journal, 30, 207-222. https://doi.org/10.1080/08853908.2016.1155513

[12] Haltmaier, J. (2014) Cyclically Adjusted Current Account Balances. US Federal Reserve Board's International Finance Discussion Papers, No. 1126, 1-25. https://doi.org/10.2139/ssrn.2536569

[13] Choi, S., Lim, S. and Phillips, J. (2009) Responsible Entrepreneurship, Nation Brand, and Public Policy. Korea Observer, 40, 369-392.

[14] Siu, N.Y.M., Kwan, H.Y. and Zeng, C.Y. (2016) The Role of Brand Equity and Face Saving in Chinese Luxury Consumption. Journal of Consumer Marketing, 33, 245-256. https://doi.org/10.1108/JCM-08-2014-1116

[15] Stahl, F., Heitmann, M., Lehmann, D. and Neslin, S. (2012) The Impact of Brand Equity on Customer Acquisition, Retention, and Profit Margin. Journal of Marketing, 76, 44-63. https://doi.org/10.1509/jm.10.0522

[16] Gross, C.M. (2013) The Growth of China's Technology Transfer Industry over the Next Decade: Implications for Global Markets. Journal of Technology Transfer, 38, 716-747. https://doi.org/10.1007/s10961-012-9263-x

[17] Jung, J.C., Ugboma, M.A. and Liow, A.K. (2015) Does Alibaba's Magic Work outside China? Thunderbird International Business Review, 57, 505-518. https://doi.org/10.1002/tie.21739

[18] Verbeke, A. and Kano, L. (2015) The New Internalization Theory and Multinational Enterprises from Emerging Economies: A Business History Perspective. Business History Review, 89, 415-445. https://doi.org/10.1017/S0007680515000689

[19] Haynie, D. (2017) These Are the World's Most Influential Countries. US News and World Report.

https://www.usnews.com/news/best-countries/best-international-influence

[20] Deng, P. (2012) The Internationalization of Chinese Firms: A Critical Review and Future Research. International Journal of Management Reviews, 14, 408-427. https://doi.org/10.1111/j.1468-2370.2011.00323.x

[21] Gondhia, N. (2015) Why Are Chinese Brands Seen Poorly in the US and What Can They Do about It? https://www.androidauthority.com/perception-chinese-brands-usa-643979/

[22] Schivinski, B. and Dąbrowski, D. (2014) The Consumer-Based Brand Equity Inventory: Scale Construct and Validation. GUT FME Working Paper Series A, Gdansk University of Technology, Gabriela Narutowicza. https://search.proquest.com/docview/1698382388?accountid=158816

[23] Netemeyer, R.G., Krishnan, B., Pullig, C. and Wang, G. (2004) Developing and Validating Measures of Facets of Customer-Based Brand Equity. Journal of Business Research, 57, 209-224. https://doi.org/10.1016/S0148-2963(01)00303-4 
[24] Zafar, F., Javaid, K., Amin, H. and Hammad, A. (2017) Social Media Marketing Retains Brand Equity during Product Crisis. Advances in Social Sciences Research Journal, 4. https://doi.org/10.14738/assrj.413.2708

[25] Southworth, S.S. and Ha-Brookshire, J. (2016) The Impact of Cultural Authenticity on Brand Uniqueness and Willingness to Try. Asia Pacific Journal of Marketing and Logistics, 28, 724-742. https://doi.org/10.1108/APJML-11-2015-0174

[26] Keller, K.L. (2003) Strategic Brand Management. 4th Edition, Prentice Hall, Upper Saddle River, NJ.

[27] Aaker, D.A. (2009) Managing Brand Equity: Capitalizing on the Value of a Brand Name. The Free Press, New York.

[28] Li, F., Xu, L., Li, T. and Zhou, N. (2015) Brand Trust in a Cross-Cultural Context: Test for Robustness of an Alternative Measurement Model. Journal of Product \& Brand Management, 24, 462-471. https://doi.org/10.1108/JPBM-10-2014-0735

[29] Clemons, E.K., Wilson, J., Matt, C., Hess, T., Ren, F., Jin, F. and Koh, N.S. (2016) Global Differences in Online Shopping Behavior: Understanding Factors Leading to Trust. Journal of Management Information Systems, 33, 1117-1148. https://doi.org/10.1080/07421222.2016.1267531

[30] Didier, L. and Lombart, C. (2010) Impact of Brand Personality on Three Major Relational Consequences (Trust, Attachment, and Commitment to the Brand). The Journal of Product and Brand Management, 19, 114-130. https://doi.org/10.1108/10610421011033467

[31] Hudders, L., Cauberghe, V., Panic, K. and De Vos, W. (2016) Children's Advertising Literacy for New Advertising Formats: The Mediating Impact of Advertising Literacy on the (Un) Intended Effects of Advergames and Advertising Funded Programs. In: Verlegh, P., Voorveld, H. and Eisend, M., Eds., Advances in Advertising Research. European Advertising Academy, Springer Gabler, Wiesbaden. https://doi.org/10.1007/978-3-658-10558-7_19 